\title{
EVALUASI PENERIMAAN PAJAK USAHA MIKRO KECIL DAN MENENGAH (UMKM) PASCA PENERBITAN PERATURAN PEMERINTAH NOMOR 23 TAHUN 2018 DI KOTA TOMOHON
}

\author{
Bernita Siallagan ${ }^{1}$, Ventje Ilat ${ }^{1}$, Tresjee Runtu ${ }^{1}$ \\ ${ }^{1}$ Jurusan Akuntansi, Fakultas Ekonomi dan Bisnis, Universitas Sam Ratulangi, Jl. Kampus Bahu, Manado, \\ 95115, Indonesia \\ E-mail: bernitasiallagan@gmail.com
}

\begin{abstract}
Micro, Small and Medium Enterprises are business sectors that have large tax revenue opportunities. The development of Micro, Small and Medium Enterprises (MSMEs) contributes positively to the handling of economic and social problems. Micro, Small and Medium Enterprises (MSMEs) can help the government in reducing poverty, reducing the amount of unemployment, and social inequality. In helping to increase this small and medium economic activity, the government provides tax services for MSME taxpayers with a $0.5 \%$ tax rate on gross income not exceeding Rp4.8 Billion. PP No. 23 of 2018 concerning the imposition of MSME tax. This study aims to evaluate how the level of UMKM tax revenue when PP No. 46 of 2013 and when the PP No. 23 of 2018. The method used in this study is a comparative descriptive analysis method. The results showed that the growth of taxpayers who make payments increased while UMKM tax revenues decreased due to tariff cuts.

Keywords: regulation; revenue;taxpayer; income tax;micro small and medium enterprise
\end{abstract}

\section{PENDAHULUAN}

Indonesia merupakan salah satu negara berkembang yang sedang gencar-gencarnya melakukan pembangunan di segala bidang baik itu di bidang sarana prasarana yang menunjang kebutuhan masyarakat dalam negeri maupun bidang ekonomi. Pembangunan ini bertujuan untuk mensejahterakan kehidupan rakyat dan juga untuk mensukseskan pembangunan nasional. Peranan penerimaan dalam negeri dianggap begitu penting serta mempunyai kedudukan yang strategis untuk mensukseskan pembangunan nasional. Roda pemerintahan dan pembangunan tidak akan berjalan tanpa adanya dukungan dana. Dana tersebut bersumber dari penerimaan yang berasal dari penerimaan pajak dan penerimaan bukan pajak.

Di Indonesia, sumber penerimaan terbesar dan penyumbang dana terbanyak adalah pajak. Pajak merupakan sumber penerimaan yang diandalkan jika dibandingkan dengan penerimaan dari sumber daya alam yang suatu saat akan habis (Budiarso et al., 2019), oleh karena itu pemerintah sangat mengandalkan penerimaan dari sektor perpajakan sebagai salah satu sumber penerimaan negara. Pajak adalah iuran rakyat kepada kas negara berdasarkan undang-undang (yang dapat dipaksakan) dengan tiada mendapat jasa timbal (kontraprestasi) yang langsung dapat ditunjukkan dan yang digunakan untuk membayar pengeluaran umum (Mardiasmo, 2016:1). Pengertian pajak tersebut secara langsung mempunyai potensi yang sangat mungkin untuk menjadi sumber penerimaan negara yang dapat diandalkan pajak memegang peranan yang sangat penting untuk kelangsungan sistem pemerintahan.

Direktorat Jenderal Pajak (DJP) berusaha meningkatkan penerimaan pajak diantaranya dengan cara meningkatkan jumlah Wajib Pajak (WP) terdaftar secara terus menerus dan dengan melakukan reformasi kebijakan perpajakan salah satunya kebijakan pada bidang Usaha Mikro Kecil dan Menengah (UMKM). Usaha Mikro Kecil dan Menengah (UMKM) memiliki peluang pemasukan pajak yang besar. Pemerintah pun melakukan 
berbagai cara untuk meningkatkan penerimaan pajak khususnya pajak Usaha Mikro Kecil dan Menengah (UMKM) baik itu melakukan revisi dalam peraturan perpajakan yang lama ataupun penerapan baru dari undang-undang dan Peraturan daerah dalam upaya mendorong pemenuhan kewajiban perpajakan serta mendorong penerimaan Negara dari Usaha Mikro Kecil dan Menengah (UMKM).

Peraturan pajak mengalami revisi seperti peraturan yang mengatur pajak untuk para pelaku Usaha Mikro Kecil dan Menengah (UMKM) yaitu Peraturan Pemerintah Nomor 46 Tahun 2018 dengan tarif 1\% diubah ke Peraturan Pemerintah Nomor 23 Tahun 2018 dengan perubahan tarif sebesar $0,5 \%$. Alasan dibuatnya kebijakan penurunan tarif PPh Usaha Mikro Kecil dan Menengah (UMKM) adalah untuk memberikan keringanan pajak bagi Usaha Mikro Kecil dan Menengah (UMKM) dengan potongan pajak 0,5\%. Penurunan tarif diharapkan dapat menstimulasi munculnya Usaha Mikro Kecil dan Menengah (UMKM) baru untuk berkembang dan memberikan ruang untuk kesempatan berusaha dengan berkurangnya beban biaya pajak Usaha Mikro Kecil dan Menengah (UMKM) sehingga potongan tersebut dapat digunakan dalam mengembangkan usaha.

\section{TINJAUAN PUSTAKA}

Menurut APB Statement No. 4 (1970) yang berjudul Basic Concepts and Accounting Principles Underlying Financial Statements of Business Enterprises, akuntansi adalah sebuah aktivitas jasa, dimana fungsinya adalah memberikan informasi kuantitatif, terutama informasi mengenai keuangan dan entitas ekonomi yang dimaksudkan akan menjadi berguna dalam pengambilan keputusan ekonomi dalam membuat pilihan diantara berbagai alternatif yang ada (Hery, 2017:1).

Menurut Agoes (2014:10), akuntansi pajak adalah akuntansi yang diterapkan sesuai dengan peraturan perpajakan. Akuntansi pajak merupakan bagian dari akuntansi komersial yang diatur dalam Standar Akuntansi Keuangan (SAK). Akuntansi pajak hanya digunakan untuk mencatat transaksi yang berhubungan dengan perpajakan. Dengan adanya akuntansi pajak WP dapat dengan lebih mudah menyusun SPT. Sedangkan akuntansi komersial disusun dan disajikan berdasarkan SAK. Namun, untuk kepentingan perpajakan, akuntansi komersial harus disesuaikan dengan aturan perpajakan yang berlaku di Indonesia.

Menurut Bank Indonesia dalam Aufar (2014:9), usaha kecil adalah usaha produktif milik warga negara Indonesia, yang berbentuk badan usaha orang perorangan, badan usaha yang tidak berbadan hukum, atau badan usaha berbadan hukum seperti koperasi bukan merupakan anak perusahaan atau cabang yang dimiliki, dikuasai atau berafiliasi, baik langsung maupun tidak langsung dengan usaha menengah atau besar. Selain itu, usaha kecil memiliki kekayaan bersih paling banyak Rp. 200,000,000 tidak termasuk tanah dan bangunan atau memiliki hasil penjualan paling banyak Rp. 200,000,000 per tahun, sedangkan usaha menengah merupakan usaha yang memiliki kriteria aset tetapnya dengan besaran yang dibedakan antara industri manufaktur (Rp. 200,000,000 s.d. Rp. 500,000,000) dan non manufaktur (Rp. 200,000,000 s.d. Rp. 600,000,000).

Menurut Hutagaol (2007:325), penerimaan pajak adalah sumber penerimaan yang dapat diperoleh secara terus menerus dan dapat dikembangkan secara optimal sesuai kebutuhan pemerintah serta kondisi masyarakat. Pajak sebagai suatu kewajiban menyerahkan sebagian dari kekayaan ke kas negara yang disebabkan suatu keadaan, kejadian, dan perbuatan yang memberikan kedudukan tertentu tetapi bukan sebagai hukuman menurut peraturan yang ditetapkan pemerintah serta dapat dipaksakan tetapi tidak ada jasa timbal balik dari Negara secara langsung untuk memelihara kesejahteraan umum (Supramono dan Damayanti, 2015:2). Menurut Suryadi (2011:105), penerimaan pajak merupakan sumber pembiayaan negara yang dominan baik untuk belanja rutin maupun pembangunan. Pajak Penghasilan bersifat final merupakan pajak penghasilan yang pengenaannya sudah final 
(berakhir) sehingga tidak dapat dikreditkan (dikurangkan) dari total Pajak Penghasilan terutang pada akhir tahun pajak (Resmi, 2013:145).

Berdasarkan surat edaran Direktorat Jenderal Pajak Kementerian Keuangan atas Peraturan Pemerintah Republik Indonesia tentang Pajak Penghasilan atas penghasilan dari usaha yang diterima atau diperoleh wajib pajak yang memiliki peredaran bruto tertentu, wajib pajak orang pribadi maupun wajib pajak badan tidak termasuk bentuk usaha tetap yang memiliki penghasilan dari usaha tidak termasuk penghasilan dari jasa sehubungan dengan pekerjaan bebas, dengan peredaran bruto tidak melebihi Rp. 4,800,000,000,- (empat milyar delapan ratus juta rupiah) dalam 1 (satu) tahun pajak dikenai tarif PPh yang bersifat final yaitu $1 \%$ (satu persen).

Besarnya tarif pajak sesuai dengan Peraturan Pemerintah Nomor 46 Tahun 2013 adalah sebesar 1\% dari Dasar Pengenaan Pajak (DPP). DPP yaitu jumlah peredaran bruto setiap bulannya dan disetor setiap bulan sebelum tanggal 15 bulan berikutnya. Tarif yang di kenakan oleh wajib pajak orang pribadi maupun badan dalam Peraturan Pemerintah Nomor 23 Tahun 2018 adalah sebesar 0,5\% dari peredaran bruto. Peredaran bruto yang dimaksud merupakan jumlah peredaran bruto dalam 1 tahun pajak terakhir sebelum tahun pajak bersangkutan yang ditentukan berdasarkan keseluruhan peredaran bruto dari usaha termasuk peredaran bruto dari cabang.

Suardana et al. (2018) menunjukkan bahwa tingkat efektivitas dan tingkat kontribusi penerapan Peraturan Pemerintah Nomor 46 Tahun 2013 secara simultan berpengaruh signifikan terhadap penerimaan pajak dan kontribusinya terhadap penerimaan pajak secara parsial berpengaruh signifikan. Prabantari dan Ardiyanto (2017) menunjukkan bahwa dari hasil kuesioner yang dibagikan adanya rasa ketidakadilan dan dirugikan atas penerapan Peraturan Pemerintah Nomor 46 Tahun 2013 pada 32 responden (UMKM) yang berada di Jawa Tengah dan Daerah Istimewa Yogyakarta. Ningrum et al. (2016) menunjukkan bahwa bentuk peraturan dalam penghasilan dari WP yang ditentukan sudah sesuai dengan ketetapan peraturan pemerintah tentang Wajib Pajak dengan Peraturan Pemerintah Nomor 46 Tahun 2013. Atawodi dan Ojeka (2012) menunjukkan bahwa masalah tingginya tarif pajak yang sebagian besar mendorong ketidakpatuhan dan mendorong sebagian besar UKM untuk tetap berada di sektor informal. Hakim dan Nangoi (2015) menunjukkan bahwa setelah penerapan Peraturan Pemerintah Nomor 46 Tahun 2013 mengalami penurunan pertumbuhan wajib pajak sebesar 0,23\%, sedangkan rata-rata penerimaan PPh Pasal 4 ayat (2) dari PPh UMKM selama tujuh belas bulan sejak pelaksanaan Peraturan Pemerintah Nomor 46 Tahun 2013 adalah sebesar 3,89\% dengan kriteria sangat kurang.

\section{METODE PENELITIAN}

Jenis penelitian yang digunakan dalam penelitian ini adalah penelitian deskriptif kualitatif dimana penelitian ini akan memberikan pemahaman atau gambaran sistematis secara fakta tentang bagaimana tingkat penerimaan pajak Usaha Mikro Kecil dan Menengah (UMKM) saat pemberlakuan Peraturan Pemerintah Nomor 46 Tahun 2013 dan sesudah Penerbitan Peraturan Pemerintah Nomor 23 Tahun 2018 di Kota Tomohon. Jenis data yang digunakan dalam penelitian ini adalah data kualitatif dan data kuantitaif. Data kualitatif berupa gambaran umum objek penelitian dan hasil wawancara dan data kuantitatif berupa data penerimaan pajak UMKM dan data jumlah wajib pajak yang melakukan pembayaran pajak UMKM di Kota Tomohon periode Juli-Desember 2017 dan Juli-Desember 2018.

Sumber data yang digunakan dalam penelitian ini adalah data sekunder yang diambil dari Kantor Pelayanan Penyuluhan dan Konsultasi Pajak (KP2KP) Kota Tomohon berupa data penerimaan pajak UMKM dan data jumlah wajib pajak yang melakukan pembayaran pajak UMKM di Kota Tomohon tahun 2017-2018 periode Juli-Desember. Metode analisis 
data yang digunakan adalah dengan metode analisis deskriptif. Adapun proses analisis yang dilakukan terdiri atas tahapan-tahapan berikut :

1. Mengumpulkan data mengenai gambaran umum objek penelitian, hasil wawancara dan dokumentasi.

2. Menyajikan data yang telah dikumpulkan dari KP2KP Tomohon.

3. Melakukan analisis dengan melakukan perbandingan antara tingkat penerimaan pajak UMKM Kota Tomohon saat pemberlakuan Peraturan Pemerintah Nomor 46 Tahun 2013 dengan tingkat penerimaan pajak UMKM Kota Tomohon saat pemberlakuan Peraturan Pemerintah Nomor 23 Tahun 2018.

4. Menetapkan hasil penelitian untuk tingkat penerimaan pajak UMKM Kota Tomohon pasca pemberlakuan Peraturan Pemerintah Nomor 23 Tahun 2018.

5. Menarik kesimpulan dari hasil penelitian untuk tingkat penerimaan pajak UMKM Kota Tomohon pasca pemberlakuan Peraturan Pemerintah Nomor 23 Tahun 2018.

\section{HASIL PENELITIAN DAN PEMBAHASAN}

\subsection{Hasil penelitian}

Berdasarkan hasil wawancara dengan Bapak Binsar Nikolaidus maka dapat disimpulkan bahwa Peraturan Pemerintah Nomor 23 Tahun 2018 merupakan peraturan baru yang ditetapkan oleh pemerintah yang mengatur tentang sistem perpajakan UMKM pengganti Peraturan Pemerintah Nomor 46 Tahun 2013. Peraturan Pemerintah Nomor 46 Tahun 2013dan Peraturan Pemerintah Nomor 23 Tahun 2018 memiliki perbedaan tarif yaitu penurunan tarif dari $1 \%$ ke $0,5 \%$. Tujuan pemerintah melakukan pergantian dari Peraturan Pemerintah Nomor 46 Tahun 2013 ke Peraturan Pemerintah Nomor 23 Tahun 2018 yaitu, supaya wajib pajak yang memiliki peredaran bruto tertentu untuk dapat menyelenggarakan pembukuan sebelum dikenai pajak penghasilan dengan rezim umum sehingga lebih mudah dalam melaksanakan kewajiban perpajakan, mendorong wajib pajak dalam kegiatan ekonomi formal dengan cara memberikan kemudahan dan kesederhanaan kepada wajib pajak yang memiliki peredaran bruto tertentu dalam melaksanakan kewajiban perpajakannya dengan diberikan jangka waktu tertentu, memberikan peredaran bruto tertentu yang telah mampu melakukan pembukuan sehingga wajib pajak dapat memilih untuk dikenai pajak penghasilan berdasarkan undang-undang pajak penghasilan.

Penerapan Peraturan Pemerintah Nomor 23 Tahun 2018 ini pada KP2KP Kota Tomohon dilakukan pada bulan Juli 2018 sama halnya dengan Kantor Pelayanan Pajak di kota-kota lainnya. Banyak yang tidak mengetahui pergantian peraturan ini, khususnya pelaku UMKM yang berada di Kota Tomohon, maka KP2KP Kota Tomohon melakukan usahausaha untuk memperkenalkan peraturan ini, seperti melakukan sosialisasi agar masyarakat paham dengan peraturan ini terlebih dahulu supaya masyarakat khususnya UMKM dapat melakukannya, mengundang wajib pajak ke kantor, kunjungan langsung ke lokasi usaha wajib pajak (door to door), penyebaran informasi melalui media ruang seperti baliho, banner, spanduk dan brosur. usaha-usaha yang dilakukan oleh KP2KP Kota Tomohon dalam memperkenalkan Peraturan Pemerintah Nomor 23 Tahun 2018 tanggapan masyarakat sangat antusias dan puas dikarenakan tarif yang diberlakukan dalam peraturan ini mengalami penurunan. Setelah pergantian peraturan ini, maka jumlah wajib pajak yang melakukan pembayaran terjadi peningkatan secara signifikan sedangkan dilihat dari sisi jumlah penerimaan pajaknya terjadi penurunan yang disebabkan perubahan tarif dari $1 \%$ ke $0,5 \%$. 


\subsection{Pembahasan}

Tabel 1 menunjukkan bahwa total jumlah wajib pajak yang melakukan pembayaran pada periode Juli-November 2017 hingga periode Juli-November 2018 mengalami peningkatan, tetapi pada bulan Desember 2017 ke Desember 2018 mengalami penurunan. Pertumbuhan tertinggi terjadi pada bulan Agustus yakni mencapai 193 wajib pajak dengan persentase pertumbuhan $128,67 \%$.

Tabel 1. Pertumbuhan pembayaran wajib pajak periode Juli-Desember

\begin{tabular}{|c|c|c|c|c|}
\hline Bulan & 2017 & 2018 & $\begin{array}{c}\text { Pertumbuhan } \\
\text { jumlah WP yang } \\
\text { melakukan } \\
\text { pembayaran }\end{array}$ & $\begin{array}{c}\text { Persentase } \\
\text { pertumbuhan }\end{array}$ \\
\hline Juli & 298 & 299 & 1 & $0.34 \%$ \\
\hline Agustus & 150 & 343 & 193 & $128.67 \%$ \\
\hline September & 205 & 285 & 80 & $39.02 \%$ \\
\hline Oktober & 197 & 282 & 85 & $43.15 \%$ \\
\hline November & 242 & 333 & 91 & $37.60 \%$ \\
\hline Desember & 256 & 252 & -4 & $-1.56 \%$ \\
\hline \multicolumn{3}{|c|}{ Rata-rata } & 74 & $41.20 \%$ \\
\hline
\end{tabular}

Sumber: Data diolah, 2019

Pertumbuhan terendah terjadi pada bulan Desember yakni mengalami penurunan sebesar 4 wajib pajak sehingga persentase pertumbuhannya mengalami penurunan sebesar $1,56 \%$ seperti yang ditunjukkan pada Gambar 1 .

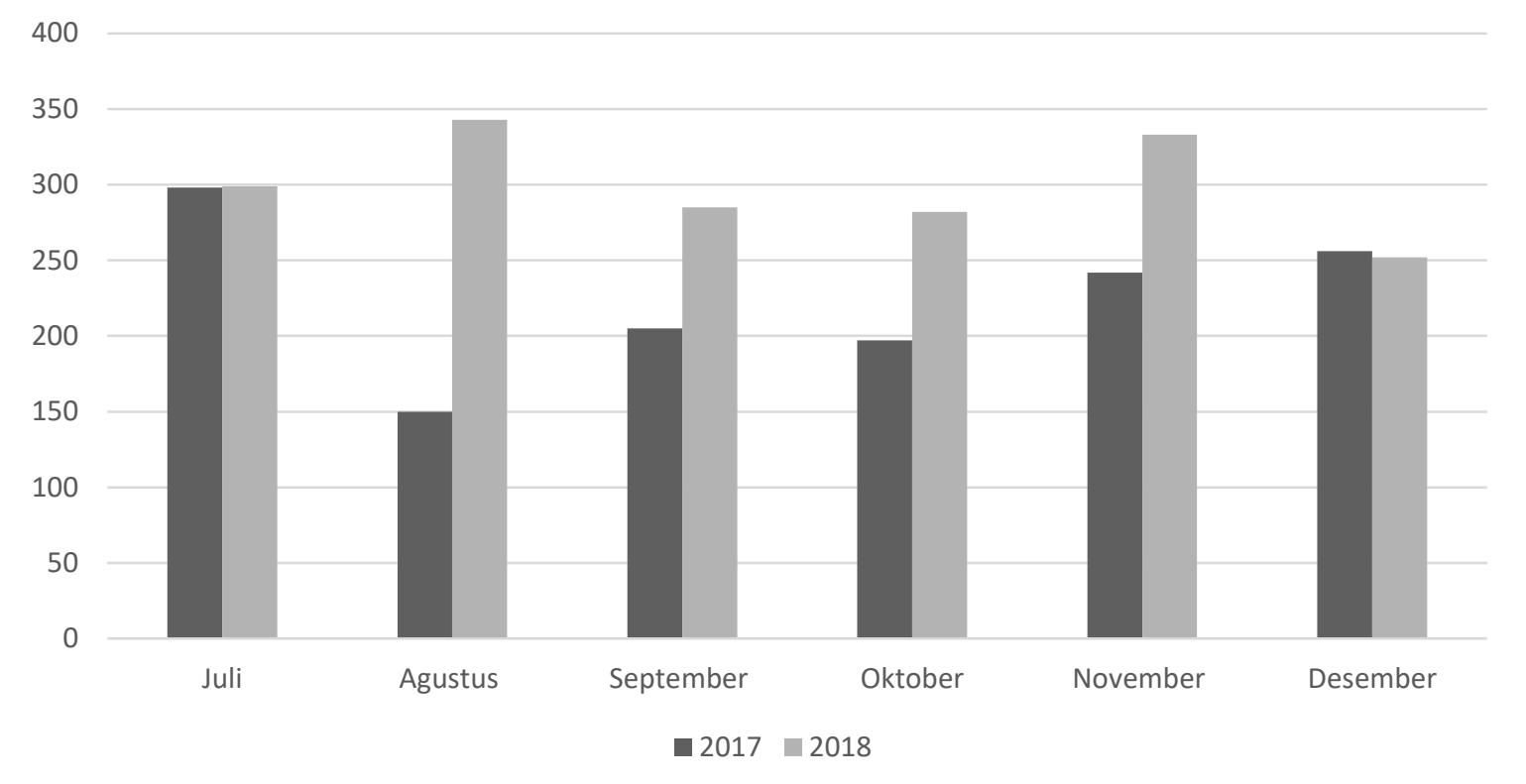

Gambar 1. Pertumbuhan Wajib pajak yang melakukan pembayaran periode Juli-Desember

Besarnya perbandingan penerimaan pajak saat pemberlakuan Peraturan Pemerintah Nomor 46 Tahun 2013 dan saat pemberlakuan Peraturan Pemerintah Nomor 23 Tahun 2018 selama periode Juli-Desember tahun 2017-2018 bersifat fluktuatif, artinya terdapat peningkatan dan penurunan dari besarnya penerimaan PPh UMKM. Penerimaan PPh UMKM 
terendah terdapat pada bulan November yaitu mengalami penurunan sebesar $26,27 \%$ sedangkan PPh UMKM mengalami peningkatan pada bulan Agustus yaitu sebesar 58,71\%.

Tabel 2. Tingkat penerimaan PPh final periode Juli-Desember

\begin{tabular}{|c|c|c|c|c|}
\hline Bulan & 2017 & 2018 & $\begin{array}{c}\text { Tingkat } \\
\text { Penerimaan }\end{array}$ & Persentase \\
\hline Juli & 92.660 .000 & 94.260 .000 & 1.600 .000 & $1.73 \%$ \\
\hline Agustus & 56.817 .000 & 90.172 .000 & 33.355 .000 & $58.71 \%$ \\
\hline September & 66.380 .000 & 71.566 .000 & 5.186 .000 & $7.81 \%$ \\
\hline Oktober & 78.455 .000 & 66.217 .000 & $(12.238 .000)$ & $-15.60 \%$ \\
\hline November & 75.200 .000 & 62.768 .000 & $(12.432 .000)$ & $-16.53 \%$ \\
\hline Desember & 91.096 .000 & 67.177 .000 & $(23.919 .000)$ & $-26.27 \%$ \\
\hline Total & 460.608 .000 & 452.160 .000 & $(8.448 .000)$ & $9.58 \%$ \\
\hline
\end{tabular}

Sumber : Data Diolah, 2019

Penerimaan total PPh UMKM saat pemberlakuan Peraturan Pemerintah Nomor 23 Tahun 2018 lebih sedikit daripada hasil penerimaan total PPh UMKM saat pemberlakuan Peraturan Pemerintah Nomor 46 Tahun 2013. Hal ini dikarenakan adanya perubahan tarif yang sebelumnya $1 \%$ menjadi $0,5 \%$ dari peredaran bruto sebelumnya. Tabel 2 juga menunjukkan bahwa penerimaan bulan Oktober sampai dengan Desember mengalami penurunan hal ini dikarenakan beberapa faktor. Adapun faktor yang mempengaruhi penurunan penerimaan pada bulan Oktober sampai dengan bulan Desember yaitu karena awal berlaku peraturan baru ini di bulan Juli sehingga peraturan ini masih perlu untuk di sosialisasikan agar wajib pajak mengetahuinya. Adanya beberapa wajib pajak yang telah mengetahui peraturan ini menyebabkan berfluktuasinya pola pembayaran yang disebabkan oleh tarif pajak yang telah mengalami penurunan $0,5 \%$ dan keterlambatan penyetoran oleh wajib pajak sehingga hal ini berdampak pada penurunan penerimaan seperti yang ditunjukkan pada Gambar 2.

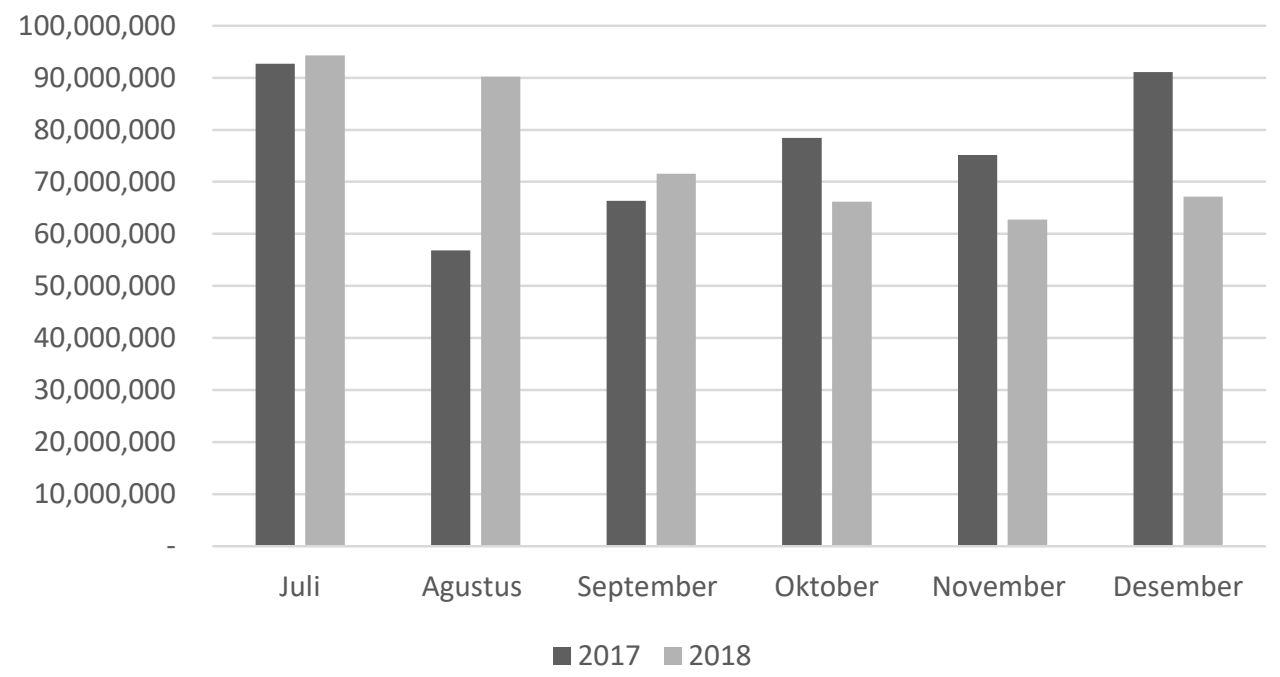

Gambar 2. Tingkat Penerimaan Pajak UMKM Periode Juli-Desember 


\section{KESIMPULAN DAN SARAN}

\subsection{Kesimpulan}

Penelitian ini menyimpulkan bahwa terjadi peningkatan wajib pajak yang melakukan pembayaran pajak UMKM sebesar 74 wajib pajak dengan persentase sebesar 41,20\%. Penerimaan PPh UMKM setelah pemberlakuan Peraturan Pemerintah Nomor 23 Tahun 2018 mengalami penurunan dikarenakan penurunan tarif $\mathrm{PPh}$ Usaha Mikro Kecil dan Menengah (UMKM) dari $1 \%$ ke 0,5\% namun penurunan yang terjadi tidak terlalu besar. Hal ini menunjukkan bahwa upaya Direktorat Jenderal Pajak untuk meningkatkan kesadaran wajib pajak dalam melakukan pembayaran pajak UMKM setelah pemberlakuan Peraturan Pemerintah Nomor23 Tahun 2018 ini sudah mulai tercapai.

\subsection{Saran}

Saran dari penelitian ini untuk Direktorat Jenderal Pajak secara khusus KP2KP Kota Tomohon adalah meningkatkan identifikasi potensi penerimaan pajak khususnya $\mathrm{PPh}$ UMKM. Selain itu, Direktorat Jenderal Pajak secara khusus KP2KP Kota Tomohon perlu meningkatkan sosialisasi tentang penerapan Peraturan Pemerintah Nomor 23 Tahun 2018 yang tergolong masih baru agar tujuan dan sasaran dari peraturan ini sampai kepada masyarakat khususnya pelaku UMKM.

\section{DAFTAR PUSTAKA}

Accounting Principles Board. (1970). APB Statement No. 4 basic concept and accounting principles underlying financial statement of business enterprises. Amerika Serikat: AICPA.

Agoes, S., \& Trisnawati, E. (2014). Akuntansi perpajakan, Edisi 3. Jakarta: Salemba Empat. Atawodi, O. W., \& Ojeka, S. A. (2012). Factors that affect tax compliance among small and medium enterprises (SMEs) in North Central Nigeria. International Journal of Business and Management, 7(12), 87-96. http://eprints.covenantuniversity.edu.ng/id/eprint/8496

Aufar, A. (2014). Faktor-faktor yang mempengaruhi penggunaan informasi akuntansi pada UMKM (Survei pada perusahaan rekanan PT. PLN (Persero) di Kota Bandung). https://repository.widyatama.ac.id/xmlui/handle/123456789/3060

Budiarso, N. S., Pontoh, W., \& Wokas, H. R. (2019). Ipteks penghitungan pajak penghasilan terutang berdasarkan PP nomor 23 tahun 2018 di Kelurahan Malendeng Kecamatan Paal 2 Kota Manado. Jurnal Ipteks Akuntansi bagi Masyarakat,3(1), 9-16. https://doi.org/10.32400/jiam.3.1.2019.23303

Hakim, F., \& Nangoi, G. B. (2015). Analisis penerapan PP. No. 46 tahun 2013 tentang pajak penghasilan UMKM terhadap tingkat pertumbuhan wajib pajak dan penerimaan $\mathrm{PPh}$ pasal 4 ayat (2) pada KPP pratama Manado. Jurnal EMBA: Jurnal Riset Ekonomi, Manajemen, Bisnis dan Akuntansi, 3(1), 797-795. https://ejournal.unsrat.ac.id/index.php/emba/article/view/7553

Hery. (2017). Teori akuntansi: Pendekatan konsep dan analisis. Jakarta: PT Grasindo.

Hutagaol, J. (2007). Perpajakan: Isu-isu kontemporer. Yogyakarta: Graha Ilmu.

Mardiasmo. (2016). Perpajakan, Edisi revisi. Yogyakarta: Penerbit Andi.

Ningrum, Y. M., Handayani, S. R., \& Mayowan, Y. (2016). Implementasi Peraturan Pemerintah Nomor 46 tahun 2013 tentang penghasilan yang diperoleh wajib pajak sektor UMKM (Studi pada Kantor Pelayanan Pajak Pratama Sidoarjo Selatan). Jurnal Mahasiswa 
Republik Indonesia. (2013). Peraturan Pemerintah Nomor 46 tentang pajak penghasilan atas penghasilan dari usaha yang diterima atau diperoleh wajib pajak yang memiliki peredaran bruto tertentu.

Republik Indonesia. (2018). Peraturan Pemerintah Nomor 23 tentang pajak penghasilan atas penghasilan dari usaha yang diterima atau diperoleh wajib pajak yang memiliki peredaran bruto tertentu.

Prabantari, F., \& Ardiyanto, M. D. (2017). Implementasi pajak penghasilan berdasarkan Peraturan Pemerintah Nomor 46 tahun 2013 (Studi pada UMKM di Jawa Tengah dan Daerah Istimewa Yogyakarta). Diponegoro Journal of Accounting, 6(4), 399-410. https://ejournal3.undip.ac.id/index.php/accounting/article/view/18694

Resmi, S. (2013). Perpajakan: Teori dan kasus, Edisi 7. Jakarta: Salemba Empat.

Suardana, I. M., Yuliati, N. N., \& Randy, R. (2018). Analisis pengaruh efektivitas dan kontribusi penerapan Peraturan Pemerintah Nomor 46 tahun 2013 terhadap penerimaan pajak pada Kantor Pelayanan Pajak di Pulau Lombok. Valid Jurnal Ilmiah, 15(1), 46-57. http://journal.stieamm.ac.id/index.php/valid/article/view/49

Supramono., \& Damayanti, T. W. (2015). Perpajakan Indonesia. Yogjakarta: Penerbit Andi. 